\title{
Future Challenges for the Re-use of local waste water in agricultural applications: Utilization of iron oxide (magnetite) nanoparticles to remove the heavy metals
}

\author{
Sherine M. Shehata ${ }^{1}$, Sahar M. Ismail ${ }^{1}$ and Nehal A. Ali ${ }^{2,3}$ \\ ${ }^{1}$ Soil Physics and Chemistry Department, Water Resources and Desert Soils Division, Desert Research Centre, 1 El-Mataria St., Cairo, Egypt \\ ${ }^{2}$ Center of Imaging and Microscopy, Zewail City of Science and Technology, Cairo, Egypt. \\ ${ }^{3}$ Department of Engineering Physics and Mathematics, Faculty of Engineering, Tanta University, Egypt. \\ Corresponding authors: Sahar Mohamed Ismail \\ Soil Physics and Chemistry Department, Water Resources and Desert Soils Division, Desert Research Centre, 1 El-Mataria St., Cairo, Egypt \\ Email: dr.sahar.mohamedi@gmail.com
}

Received date: 18 March 2019, Accepted date: 26 June 2019, Online date: 29 June 2019

Copyright: (C) 2019 Sherine Shehata Marid . et al., This is an open-access article distributed under the terms of the Creative Commons Attribution License, which permits unrestricted use, distribution, and reproduction in any medium, provided the original author and source are credited.

\begin{abstract}
The usage of polluted water in the agriculture is considered as one of the most important enraging environmental problems in the twentyfirst century. A lot of studies has been conducted aiming at removing the heavy metal ions from the water using different techniques, however, magnetic magnetite nanoparticles seems as a new sorbent efficiently used for remediation of wastewater. This work represents a trial towards investigating the influence of nano-crystalline iron oxide particles on the sorption of heavy metal ions from aqueous solutions artificially contaminated with $\mathrm{Pb}, \mathrm{Ni}, \mathrm{Cd}$ and $\mathrm{Cu}$ at concentrations varying from 1 to 500 mgL-1. The Fe3O4-magnetic nanoparticles used in this work were of $22 \mathrm{~nm}$ in size. They were produced by citrate precursor technique and distinguished by X-ray diffraction (XRD), transmission electron microscopy (TEM), the M-H curve and their adsorption properties (specific surface area and pore size distribution) including chemical structure and morphology. In the sorption study, batch technique was conducted under experimental conditions like pH of aquatic solution ( 1 - 5), shaking time $\left(1-120\right.$ minutes), different masses of sorbent $\left(0.05-0.25\right.$ g) and temperature regime $\left(25-50{ }^{\circ} \mathrm{C}\right)$. Results indicated that maximum sorption values of the studied heavy metals were achieved after 30 minutes and greatly dependent on solution $\mathrm{pH}$. The sorption data for $\mathrm{Ni2}+, \mathrm{Pb} 2+$, and $\mathrm{Cu} 2+$ were best fitted to both Langmuir and Freundlich sorption isotherm models due to their high $\mathrm{R} 2$ and low SE for both models. The constants of these models showed that the nano-Fe2O3 particles have high affinity to retain $\mathrm{Pb}$ followed by $\mathrm{Ni}, \mathrm{Cd}$ and for less extent $\mathrm{Cd}$. Generally, it could be deduced that the nano-crystalline Fe3O4 magnetic particle sorbent is a promising material for removal of the heavy metals from aqueous solutions.
\end{abstract}

Key words: Heavy metals removal; waste water; Iron oxide nanoparticles; adsorption isotherm

\section{INTRODUCTION}

The humanity faces huge pollution problems due to rapid growth of the industrial activities (e.g. fertilizer industries, tanneries, paper industries, pesticides.... etc.) and the increase in human population, and their corresponding domestic and agricultural activities (Schwarzenbach et al., 2010). Massive amounts of water polluted with heavy metals are delivered to the soil environment on daily bases (Srivastava and Majumder, 2008). Human suffers from myriad of health complications and diseases due to the exposure to these toxic heavy metals. Pollution becomes one of the serious environmental problems in the world (AlMusharsfi et al., 2013; Fujita et al., 2014; Akinci et al., 2013 and Naser, 2013) particularly in the countries of the third world (Srivastava and Majumder,2008). Therefore, offering safe water is the greatest human population demand for their better health (Schwarzenbach et al., 2010). There are several traditional methods used to eliminate metals from water. The most usually used methods depend on the chemical precipitation (Wang, et al., 2004). However, these methods are not effective when significant amounts of heavy metals are to be removed (Rickerby and Morrison, 2007). The distillation technique is the famous removal method, but it is not economically efficient as it consumes large amount of energy (Bloomfield, 2011). Also, using the method of 
Citation: Sherine Shehata Marid et al., Future Challenges for the Re-use of local waste water in agricultural applications: Utilization of iron oxide (magnetite) nanoparticles to remove the heavy metals. Australian Journal of Basic and Applied Sciences, 13(6): 39-50. DOI: 10.22587/ajbas.2019.13.6.5

freezing salty water is only available in freezing atmosphere (koop et al., 2000). Reverse osmosis is versatile technique to separate fresh water from salt water and it is also utilized for the water purification from metals (Sunil and Wimalawansa, 2013). The application of high pressure on the salt-water part causes the flow of water molecules from the salt-water to the freshwater part, that it is dynamic reversible from high to low concentration (Büchner, et al., 1989). Recently, nano-based adsorbents are the more convenient innovative treatment tool for the water purification from heavy metals with low cost (Zang and Fang, 2010; Hua et al., 2012; Kharisov et al., 2012 and Feng et al., 2012). The synthesis and applicability of iron oxide nanoparticles is intensively developed in different fields for their vital important functions. Nano-materials based on iron oxide have been extensively researched in the last century as they exhibit novel property and functionality due to their small size, high surface area, and magnetic characteristics (Karatapanis et al., 2012; Xu et al., 2012 and Warner et al., 2012). Hence, in the nano-crystalline phase, properties change and these properties alterations are forcefully relay on the environment and methodology of preparation (Oh and Park, 2011; Laurent et al, 2008; Reddy et al, 2012 and Mahmoudi et al, 2011). Various chemical methods e.g. sol-gel (Farea, et al., 1999), co-precipitation (Gul et al., 2007), hydrothermal (Wang and Kung, 2004), auto-combustion synthesis (Wahbaa et al., 2014), etc. have been assigned for generation of nano-sized materials. Although, techniques of co-precipitation and hydrothermal produce small size particles, yet they are cost-effective for large-scale production, involve comparatively long time of preparation and suffering from losing metal ions during washing and ventilation processes (Kandpal et al, 2014). Lately, citrate-precursor method has widely been applied to synthesize iron oxides with many structures by mixing organic compounds (as citric acid) with metal nitrates to make the combustion reaction effectively. During the reaction, the citric acid is used as the fuel for the combustion, while metal nitrates act as suppliers of cations. The produced powders by this technique appear fine in size and have homogeneous chemical composition. In addition, citric acid is efficient in forming complexes with the metal cations, preventing the precipitation of hydroxylated compounds (Shoeb Anwar, et al, 2019). Many kinds of nano-materials were investigated as effective sorbents for removing of heavy metal ions from wastewater, including nano-carbon, nano-metal particles, and polymersupported nanoparticles (Araneda et al., 2008; Banfield and Zhang, 2001; Zhao et al., 2010; Wang et al., 2012, Lee et al., 2010 and Gupta et al., 2011). Application of iron oxide based-nanomaterial is more likable for removing the heavy metal from the contaminated water owing to their significant features like small size, high surface area, and magnetic property (Liu et al., 2012; Zhou et al., 2009 and $\mathrm{Wu}$ et al., 2012). This work aims at (1) investigating the impact of iron oxide $\left(\mathrm{Fe}_{3} \mathrm{O}_{4}\right)$ nano-particles on removing $\mathrm{Pb}^{2+}, \mathrm{Cd}^{2}+, \mathrm{Ni}^{2+}$, and $\mathrm{Cu}^{2+}$ metal ions from artificially contaminated aqueous solutions. (2) Evaluating the impacts of solution $\mathrm{pH}$, solution temperature, time of shaking and metal concentrations on controlling the efficiency of nano-material, (3) evaluating the suitability of Langmuir and Freundlich equilibrium models in describing sorption results.

\section{MATERIALS AND METHODS}

\section{Preparation of nano-iron oxide particles}

Nano-crystalline iron oxide with the chemical formula $\mathrm{Fe}_{3} \mathrm{O}_{4}$ was prepared by the citrate precursor technique. Analytical grade ferric nitrates dissolved in distilled water and reacted with citric acid $\mathrm{C}_{6} \mathrm{H}_{8} \mathrm{O}_{7}$ (anhydrous) in 1:1 molar ratio (one-hour stirring) to provide complete combustion with no residues of $\mathrm{NO}_{3}^{-}$ions remaining. The solution $\mathrm{pH}$ increased to 7 by adding ammonium hydroxide and the solution was warmed to finish the reaction to form iron citrate precursor. At $\mathrm{pH} 7$ the solution changes into viscous darker color, which recorded to provide full combustion, stronger phase formation and absence of any ammonia or nitrates in the final product. The solution was evaporated on a hot plate very slowly till around $100^{\circ} \mathrm{C}$ over a period of a few hours to dryness. As soon as the solvent removal is completed dried precursor undergoes a self-ignition reaction with dense evolution of brown gases (probably nitrogen oxides), till the entire gel was converted into burnt fluffy ash-like powder form ferrite consisting of nanoparticles. The fine powder thus obtained was heat-treated in a furnace at $250^{\circ} \mathrm{C}$ for $6 \mathrm{~h}$ and tracked by a further heat-treatment at $350^{\circ} \mathrm{C}$ for 6 hours to remove any residuals. The phase identification of the sintered nanoparticles was investigated by X-ray diffraction (XRD) performed on model X'Pert PRO with using Monochromator, Cu-radiation $(\lambda=1.542 \AA)$ at 45 K.V., 35 M.A. and scanning speed of $0.03 \%$ sec. The reflection peaks between $2 \theta=2^{\circ}$ and $60^{\circ}$, corresponding spaces (d, $\AA$ ) and relative intensities (I/Io) were obtained. The XRD spectrums and relative intensities are found and compared with ICDD files. Lattice parameter is measured from the relation $\mathrm{a}=\mathrm{d}_{\mathrm{hkl}}\left(\mathrm{h}^{2}+\mathrm{k}^{2}+\mathrm{l}^{2}\right)^{1 / 2}$, where $\mathrm{h}, \mathrm{k}_{\mathrm{s}}$ and $\mathrm{l}$ are the plane numbers and $\mathrm{d}$ is the plane spacing recorded automatically by the X-ray diffract meter. The particle size estimation performed according to Scherrer formula, $D=0.9 \lambda / \beta \cos \theta$, where $\lambda$ is the $X$ ray wavelength, $\beta$ is the full-width at half-maximum, and $\theta$ is the Bragg angle. The bulk density, $\mathrm{P}_{\mathrm{b}}$ was determined by the Archimedes method and then compared with that expected from X-ray data, $\rho_{\mathrm{XRD}}=8 M / N_{A} a^{a}$, where the number of formula units in a unit cell indicated by factor $8, M$ is the molar mass, $N_{A}$ is Avogadro's number and $a$ is cell volume, where the samples porosity was approximately valued using The X-ray density and was determined from the equation $\mathrm{P}=\left(1-\mathrm{P}_{\mathrm{b}} / \mathrm{P}_{\mathrm{XRD}}\right) \times 100$. Microstructure and morphology of the powder were described by the Transmission Electron Microscope (TEM, FEI Techni G20). The magnetization, remanent field, and coercive field were determined by tracing BH loop for the powder samples at ambient temperature using vibrating scanning magnetron and the value 
Citation: Sherine Shehata Marid et al., Future Challenges for the Re-use of local waste water in agricultural applications: Utilization of iron oxide (magnetite) nanoparticles to remove the heavy metals. Australian Journal of Basic and Applied Sciences, 13(6): 39-50. DOI: 10.22587/ajbas.2019.13.6.5

of magnetic field up to $6.5 \mathrm{kOe}$ by using the LDJ vibrating sample magnetometer (VSM) model 9600. Specific (BET) and external nanoparticle surface areas were measured by nitrogen adsorption and desorption at $77 \mathrm{~K}$, using an Autosorb 3B (Quanta chrome, MI, FL, USA) analyzer. The samples have been degassed at $423 \mathrm{~K}$ under $\mathrm{N}_{2}$ flow overnight before analysis. Surface area was obtained using the BET equation. The total pore volume (V pore), was assessed from nitrogen uptake at a relative pressure of ca. 0.97 , using the adsorption branch. $\mathrm{N}_{2}$ adsorption measurements were completed in duplicate to check the proper functioning of the equipment and the whole method, and the average values have been presented.

\section{Preparation of the aquatic solutions of heavy metals}

Nitrate stock solutions of the heavy metal ions $\mathrm{Ni}, \mathrm{Pb}, \mathrm{Cd}$ and $\mathrm{Cu}$ i.e. $\mathrm{Ni}\left(\mathrm{NO}_{3}\right)_{2}, \mathrm{~Pb}\left(\mathrm{NO}_{3}\right)_{2}, \mathrm{Cd}\left(\mathrm{NO}_{3}\right)_{2}$, and $\mathrm{Cu}\left(\mathrm{NO}_{3}\right)_{2}$ were purchased from Accu Standard®, USA. Each solution concentration was of $1000 \mathrm{mg}$ heavy metal ion $\mathrm{L}^{-1}$. Freshly prepared deionized water was used to prepare eight concentrations i.e.1, 5, 10, 25, 50, 100, 200 and $500 \mathrm{mgL}^{-1}$ (we reach to concentration $500 \mathrm{mg} / \mathrm{L}^{-1}$ to test nano-iron oxide capacity for heavy metals' adsorption) each of the heavy metals under the study. Metals analyses were conducted using Inductively Coupled Plasma Quadruple Mass Spectrometry (ICP-MS, Agilent 7500 ce). The operational data of ICP-MS in this work were briefed in Table 1.

Table 1: Operating parameters of ICP-MS Agilent 7500 ce.

\begin{tabular}{|l|l|}
\hline RF power & $1500 \mathrm{~W}$ \\
\hline Plasma gas flow & $15 \mathrm{~L} / \mathrm{min}$ \\
\hline Auxiliary gas flow & $1 \mathrm{~L} / \mathrm{min}$ \\
\hline Carrier gas flow & $1.25 \mathrm{~L} / \mathrm{min}$ \\
\hline Sampling depth & $7 \mathrm{~mm}$ \\
\hline Torch injector internal diameter & $2.5 \mathrm{~mm}$ \\
\hline Interface & $\mathrm{N}(1 \mathrm{~mm}$ sampler: $0.4 \mathrm{~mm}$ skimmer $)$ \\
\hline Ion lens voltages & Optimized for sensitivity in $10 \mathrm{ng} / \mathrm{mL}$ tune solution $(\mathrm{Li}, \mathrm{Y}, \mathrm{Ce}, \mathrm{TI})$ \\
\hline Octopole bias & $-17 \mathrm{~V}$ \\
\hline Quadrupole bias & $-13.5 \mathrm{~V}$ \\
\hline
\end{tabular}

\subsection{Batch adsorption study}

Weight portions of the iron oxide nanoparticles $(0.1 \mathrm{~g})$ were placed into $25 \mathrm{~mL}$ polytetrafluoroethylene (PTFE) tubes and each of them was mixed thoroughly with $25 \mathrm{~mL}$ of either of the previously prepared contaminated solutions. The aforementioned process was carried out under different residence periods i.e. 1, 5, 15, $30 \mathrm{~min}, 1$ and $2 \mathrm{~h}$ at an ambient temperature of $25.5 \pm 0.5 \mathrm{C}^{\mathrm{o}}$. It was found that $2 \mathrm{~h}$ was the optimum period of time to achieve the highest adsorption values of the metal ions under study, so it was used throughout the study of the effects of $\mathrm{pH}$, metal concentration, weight of the applied iron oxide nanoparticle and temperature upon which the other equilibrium experiments will be conducted. To investigate the effect of the $\mathrm{pH}$ value on the adsorption data, $25 \mathrm{~mL}$ of solutions containing $100 \mathrm{mg}$ metal ion $\mathrm{L}^{-1}$ each were equilibrated with $0.1 \mathrm{~g}$ of the iron oxide nanoparticles at room temperature $\left(25 \pm 1^{\circ} \mathrm{C}\right)$ for $2 \mathrm{~h}$ under $\mathrm{pH}$ value ranging from 1 to 5 . The concentration of the metal ion remained in the solution (equilibrium solution) was measured using the ICP-MS. Then, the adsorbed amount of the considered metal ion was calculated as the difference between the initial concentration of the metal ion and its corresponding equilibrium concentration. The removal $(\%)$ of heavy metals was calculated. For studying the consequence of the heavy metal ion concentration on the adsorption data, either of the eight different concentrations of each of the studied metal ions i.e. 1, 5, 10, 25, $50,100,200$ or $500 \mathrm{mg} \mathrm{L}^{-1}$ was equilibrated for $2 \mathrm{~h}$ with $0.1 \mathrm{~g}$ of nano-magnetite particles at ambient temperature and $\mathrm{pH}=5$. To investigate the influence of different dosage of the nano-iron oxide particles on the adsorption process of the studied metal ions, either of three different weights of the iron oxide nanoparticles (i.e. $0.05 \mathrm{~g}, 0.1 \mathrm{~g}$ and $0.25 \mathrm{~g}$ ) was equilibrated with $25 \mathrm{~mL}$ of each of the metal solutions at a concentration of $100 \mathrm{mgL}^{-1}$ at $25 \mathrm{C}^{\mathrm{o}}$, then the metal ion removal percentages were calculated at three temperature degrees $\left(25^{\circ}\right),\left(40^{\circ} \mathrm{C}\right)$, and $\left(50^{\circ} \mathrm{C}\right)$ by treating $25 \mathrm{~mL}$ of $100 \mathrm{ppm}$ of metals with $0.1 \mathrm{~g}$ of nanoparticles and kept for $2 \mathrm{~h}$.

\section{Langmuir isotherm:}

Langmuir isotherm equation suggests that adsorption occurs at specific homogeneous sites within the adsorbent. It is then supposed that once a metal ion takes up a site, no further adsorption will occur at that site. Based on that the linear form of Langmuir isotherm equation is described by equation (3):

$$
C_{e} / q_{e}=\left(1 / Q^{o} b\right)+\left(1 / Q^{o}\right) C_{e}
$$

Where $\mathrm{Q}^{\circ}$ is the maximum absorption of metal ions per unit weight of adsorbent $(\mathrm{mg} / \mathrm{g})$ associated to capacity for adsorption and $\mathrm{b}$ is Langmuir constant $(\mathrm{L} / \mathrm{mol})$ linked to sorption energy. A plot of $\mathrm{Ce} /$ qe against Ce should provide a straight line of $1 / \mathrm{Q}^{\circ}$ slope and $1 /\left(\mathrm{Q}^{\circ} \mathrm{b}\right)$ intercept. 
Citation: Sherine Shehata Marid et al., Future Challenges for the Re-use of local waste water in agricultural applications: Utilization of iron oxide (magnetite) nanoparticles to remove the heavy metals. Australian Journal of Basic and Applied Sciences, 13(6): 39-50. DOI: 10.22587/ajbas.2019.13.6.5

\section{Freundlich isotherm:}

Freundlich isotherm explains the non-ideal adsorption by adsorption equation that contains heterogeneous adsorption. This empirical isotherm is stated by equation (4):

$$
q_{e}=K_{F} C_{e}^{1 / n}
$$

The equation is appropriately used for the linear form by taking the logarithm of both sides as (Equation 5):

$$
\log q_{e}=\log K_{F}+(1 / n) \log C_{e}
$$

Freundlich constants, $\mathrm{K}_{\mathrm{F}}$ and $1 / \mathrm{n}$, are associated to adsorption capacity and intensity of adsorption, respectively. The $\mathrm{n}$ and $\mathrm{K}_{\mathrm{F}}$ values can be taken from the slope and intercept of log qe vs $\log$ Ce derived from Equation (5). The exponent 1/n provides a suggestion of the adsorption favourability. The Freundlich adsorption isotherm reflects the correlation between the corresponding adsorption capacity (qe) as $\mathrm{mg} / \mathrm{g}$ and the metal concentration of solution at equilibrium Ce (mg/L). The log (qe) versus log (Ce) for various initial concentrations was discovered to all be linear.

\section{RESULTS AND DISCUSSION}

\section{Characterization of the nano-iron oxide particles \\ X-ray diffraction}

Figure 1 illustrates the XRD data of the self-ignited sample. The found diffraction angles according to the peaks are typical of the cubic spinel structure of $\mathrm{Fe}_{3} \mathrm{O}_{4}$ phase. It is interesting to find that single phase was created directly after self-ignition from the citrate precursor with no additional peaks corresponding to extra phases which often appear at low temperatures when the reaction is not complete. A reduction in the intensity and broadening of the peaks is observed as depicted for the weakness of some diffraction lines, which indicate the relatively smaller dimension of the iron nanoparticles (Gonza'lez, et al., 2010) as prepared samples.

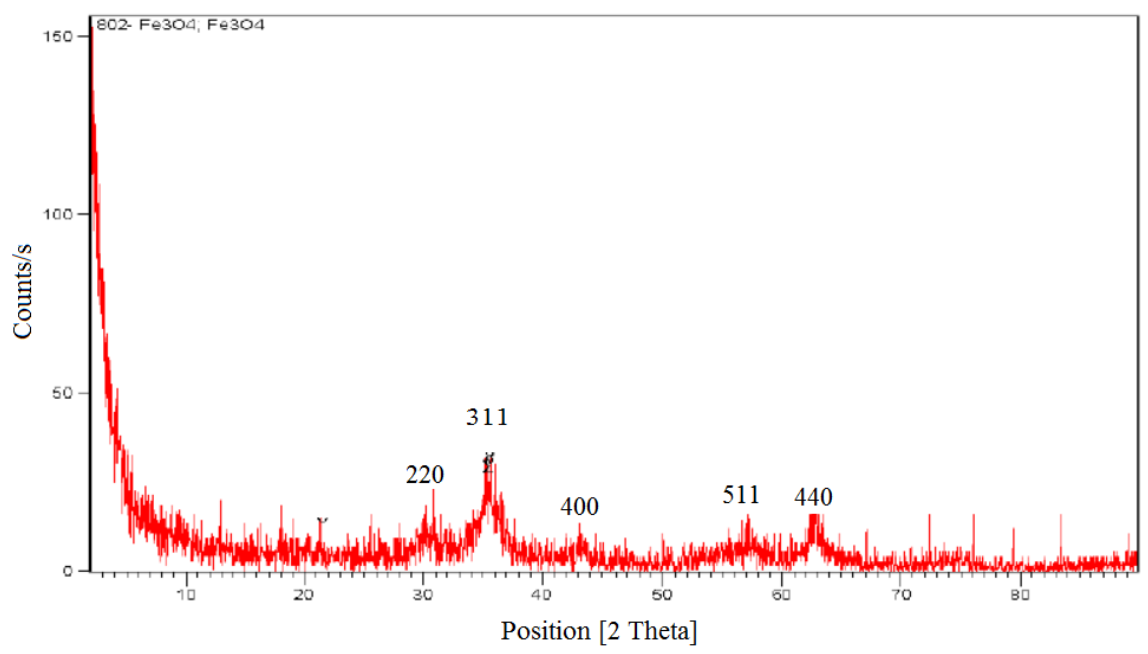

Fig. 1. X-Ray Diffraction (XRD) peaks pattern of the self-ignited $\mathrm{Fe}_{3} \mathrm{O}_{4}$ sample

The particles sizes have been figured out by using Scherrer's formula from the FWHM of 311 peak (Simamora et.al, 2018). Lattice parameter (a), particle size (D), bulk density $\left(\rho_{\mathrm{b}}\right)$ and X-ray density $\left(\rho_{\text {XRD }}\right)$, and porosity $(P)$ are presented in Table 2.

\begin{tabular}{|c|c|c|c|c|c|c|}
\hline & & $b$ & $\rho_{\mathrm{XRD}}$ & & & \\
\hline 4.3731 & 21.6 & 4.493 & 5.309 & 15.37 & 576.6 & 19.4 \\
\hline
\end{tabular}

Table 2. Structural properties of $\mathrm{Fe}_{3} \mathrm{O}_{4}$ nanoparticles

\section{TEM micrograph}

The nanostructure and the homogeneity of the particle sizes were investigated by TEM images as presented in Figure 2. The images and the diffraction pattern illustrate that particle size described by TEM, are in conformity with XRD data. Furthermore, the micrographs imply that the interaction of the iron particles increases the propensity of the small particles to agglomerate. The size distribution histogram of nanoparticles indicates that $96.4 \%$ of them are distributed between 1 to 100 nanometers (histogram of Fig. 2). 
Citation: Sherine Shehata Marid et al., Future Challenges for the Re-use of local waste water in agricultural applications: Utilization of iron oxide (magnetite) nanoparticles to remove the heavy metals. Australian Journal of Basic and Applied Sciences, 13(6): 39-50. DOI: 10.22587/ajbas.2019.13.6.5
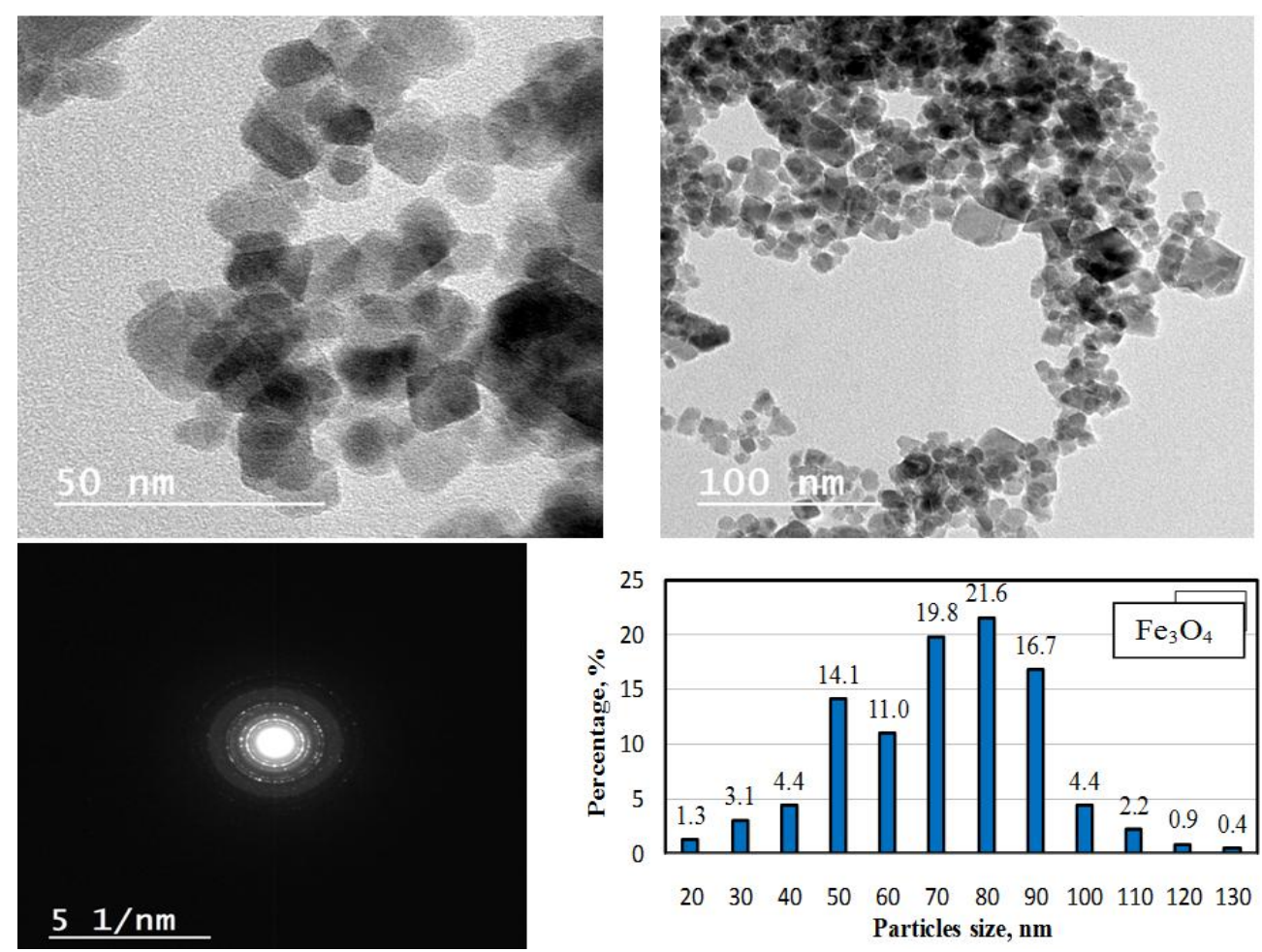

Fig. 2. TEM images and Diffraction pattern of the ferrite samples

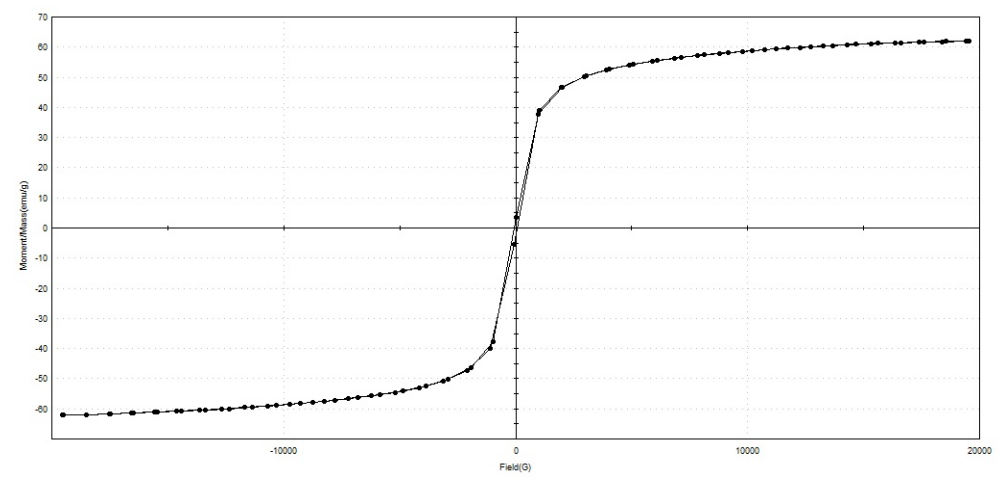

Fig.3. Room temperature magnetic hysteresis loop for the ferrite samples

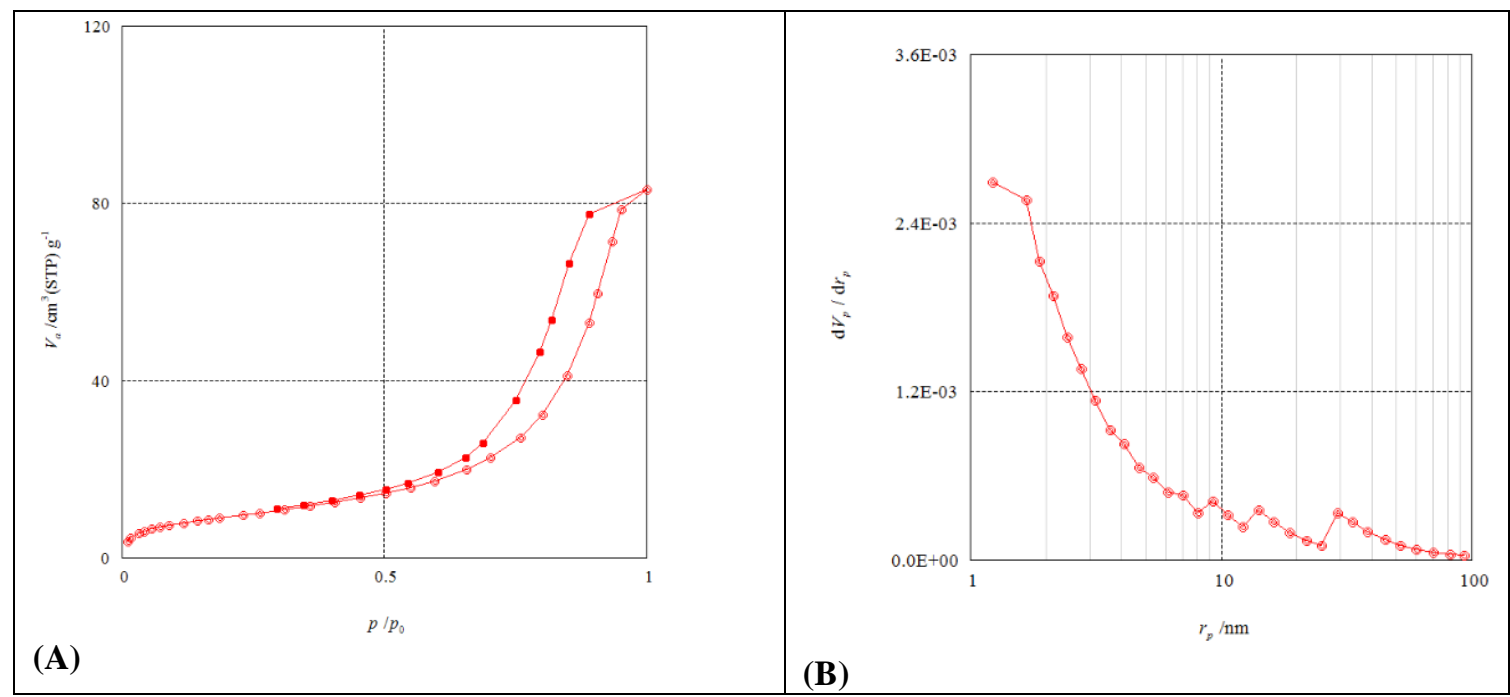

Fig. 4. $\mathrm{N}_{2}$ adsorption-desorption isotherm (A) and pore size distribution (B) of nano $\mathrm{Fe}_{3} \mathrm{O}_{4}$ sample. 
Citation: Sherine Shehata Marid et al., Future Challenges for the Re-use of local waste water in agricultural applications: Utilization of iron oxide (magnetite) nanoparticles to remove the heavy metals. Australian Journal of Basic and Applied Sciences, 13(6): 39-50. DOI: 10.22587/ajbas.2019.13.6.5

\section{Effect of studied nano-material on heavy metals adsorption from aquatic solution Effect of residence time}

The depicted data in Figure (5) represent heavy metals adsorption $\left(\mathrm{Ni}, \mathrm{Cd}, \mathrm{Pb}\right.$ and $\mathrm{Cu}$ ) on nano- $\mathrm{Fe}_{3} \mathrm{O}_{4}$ adsorbent as affected by the contact time with the studied material. The concentrations of heavy metals adsorbed on nanoparticles were determined before treatment and after shaking time. The percentage of metal removal (\%) was obtained by using the equation:

$$
\operatorname{Removal}(\%)=\left(\mathrm{C}_{\mathrm{o}}-\mathrm{C}_{\mathrm{e}}\right) / \mathrm{C}_{\mathrm{o}} \times 100
$$

Where $\mathrm{C}_{\mathrm{o}}$ is the primary concentration of the aquatic solution and $\mathrm{Ce}$ is the concentration at equilibrium after addition of nanoparticles. Results in Figure 5 indicated that lead, copper, cadmium and nickel were rapidly removed by nano- $\mathrm{Fe}_{3} \mathrm{O}_{4}$ within 30 min for solution concentration of $100 \mathrm{mg} \mathrm{L}^{-1}$. Increasing the contact time beyond $30 \mathrm{~min}$ was useless in removal water pollutants.

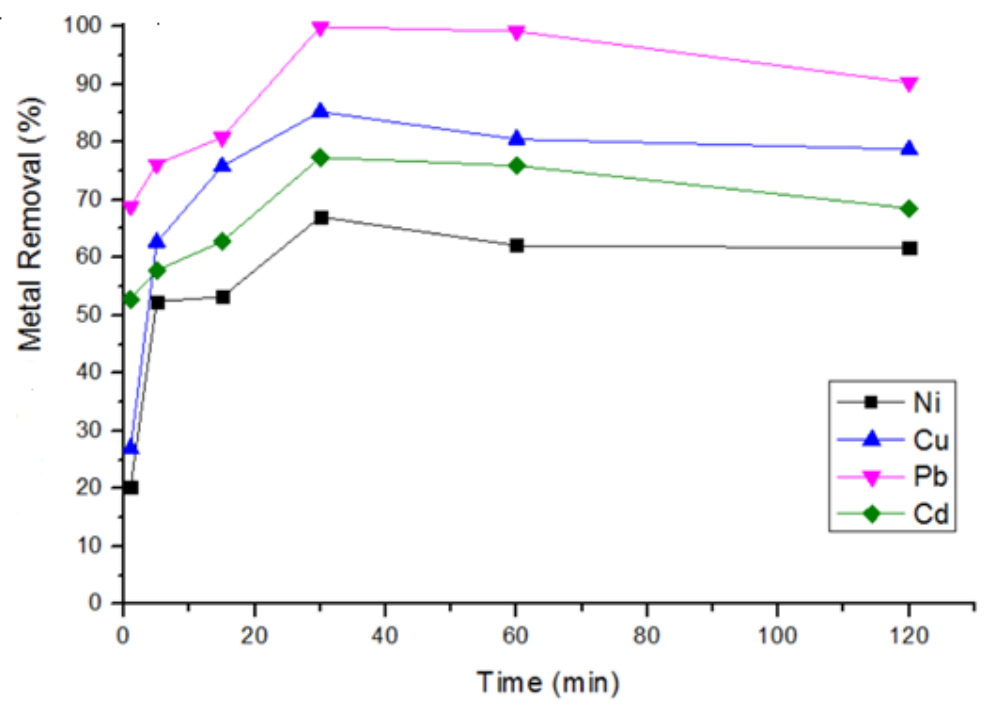

Fig. 5. Effect of contact time on heavy metals sorption on nano-Fe $\mathrm{O}_{4}$ particles (initial metal concentration $=100 \mathrm{mgL}^{-1}$, adsorbent weight, $0.1 \mathrm{~g}$, and $\mathrm{pH}=5$ under ambient room temperature).

The removal efficiency of the metal ions by the nano magnetite $\left(\mathrm{F}_{3} \mathrm{O}_{4}\right)$ adsorbent was examined as a function of residence time $(1-120 \mathrm{~min})$ with $100 \mathrm{mgL}^{-1}$ of their initial concentrations and native $\mathrm{pH}$ value of 5 . As illustrated from Fig. 5, removal efficiency increased with time of contact of all the studied metals and achieved maximum levels at 30 min. This occurred due to the availability of active bonding sites, consequently, the equilibrium status could be achieved after 30 minutes. This fits clearly with the results of Mansour et al. (2011), Tu et al. (2012), and Gutpa et al. (2012). Results also showed that there was a significant variation between different pollutants in their sorption status on nano-material. Figure (5) shows that Pb was the highest sorbed metal ion by the used nano-material followed by $\mathrm{Cu}, \mathrm{Cd}$ and $\mathrm{Ni}$ which was the lowest pollutant sorbed by nano-material. The numerical values of pollutants sorption were $100 \%, 85,75$ and $65 \%$ for $\mathrm{Pb}, \mathrm{Cu}, \mathrm{Cd}$ and $\mathrm{Ni}$, respectively. In another clarification, we could say that there was a selectivity of sorbent material for metal sorption.

\subsubsection{Effect of solution $\mathrm{pH}$ on sorption of heavy metals by studied nano-material}

It has been recognized that $\mathrm{pH}$ is one of the most important reasons that may change the rate of sorption of heavy metals in polluted waters. The experiments were executed to figure out the optimum $\mathrm{pH}$ of contaminated water reaction with tested nanomaterial. Different initial $\mathrm{pH}$ values of solutions ranged between 1 and 5 and were prepared using $0.1 \mathrm{~N}$ sodium hydroxide $(\mathrm{NaOH})$ and $0.1 \mathrm{~N} \mathrm{HCl}$ and treated with $0.1 \mathrm{~g}$ of nano- $\mathrm{Fe}_{3} \mathrm{O}_{4}$ particles at $25 \pm 0.5^{\circ} \mathrm{C}$ through 120 min. Results illustrated in Figure (6) represent the percentages of pollutants removal by the used material and the solution pHs. During the adsorption process, except for $\mathrm{Ni}$, the behaviour of metal ions in aqueous solutions was affected by the concentration of hydrogen ion. The speciation of the metal ions was affected by decreasing solution $\mathrm{pH}$ or increasing $\mathrm{H}$ ion concentrations. At $\mathrm{pH}$ less than or equal to 3 , very rapid sorption process took place. . The second stage represents almost steady state of sorption for $\mathrm{Pb}$ and a slight increase for $\mathrm{Cu}$ sorption, while a rapid increase for $\mathrm{Cd}$ sorption between $\mathrm{pH} 4-5$. This outcome was in line with the results of Zheng et al., 2010 . According to the obtained data, the adsorption capability of the adsorbent was substantially affected by the initial $\mathrm{pH}$ of the contaminated water suspension system. The removal percentage for $\mathrm{Ni}$ achieved its maximum level i.e. $63.77 \%$ at $\mathrm{pH}$ 7. $\mathrm{Ni}$ ion precipitated as Ni hydroxide and the metal was almost stable from the $\mathrm{pH}$ of 7 and 9 (Shao-hua, et al., 2012). Figure (6) reveals that the removing efficiency of $\mathrm{Pb}^{2+}$ ions from solution by the $\mathrm{Fe}_{3} \mathrm{O}_{4}$ nanoparticles was clearly pH dependent and the utmost efficiency occurred at $\mathrm{pH}=5(99.65 \%)$. Lee et al., (2010) detected a similar effect of the $\mathrm{pH}$ for the adsorption of $\mathrm{Pb}^{2+}$ onto iron oxides. It specified that higher $\mathrm{pH}$ value of the solution was favourable for the de-protonation of sorbent surface (Roonasi and Holmgren, 2009 and Johnson et al., 2000). Increased de-protonation raise sites with negatively charged, which enhanced the 
attractive forces between the sorbent surface and the $\mathrm{Pb}^{2+}$ ions. Therefore, it will increase the adsorption capacity. In contrast, in low $\mathrm{pH}$ values of suspension, sites with positive charge are controlled by repulsion forces between the sorbent and the $\mathrm{Pb}^{2+}$ ions, therefore, decreasing of $\mathrm{Pb}^{2+}$ ions adsorption was detected. Also, the removal percentage of $\mathrm{Cu}^{2+}$ and $\mathrm{Cd}^{2+}$ ions by nano- $\mathrm{Fe}_{3} \mathrm{O}_{4}$ particles increased to the maximum percentages ( 81.23 and $77.34 \%$, respectively) when the $\mathrm{pH}$ increased to 5 . The metal sorption increased at low $\mathrm{pH}$ levels $(\mathrm{pH}=5)$ as a result of metal ions has been precipitated as hydroxides confirmed from the clear solution of the suspension. This outcome is in line with the conclusion of Lee, et al. (2010).

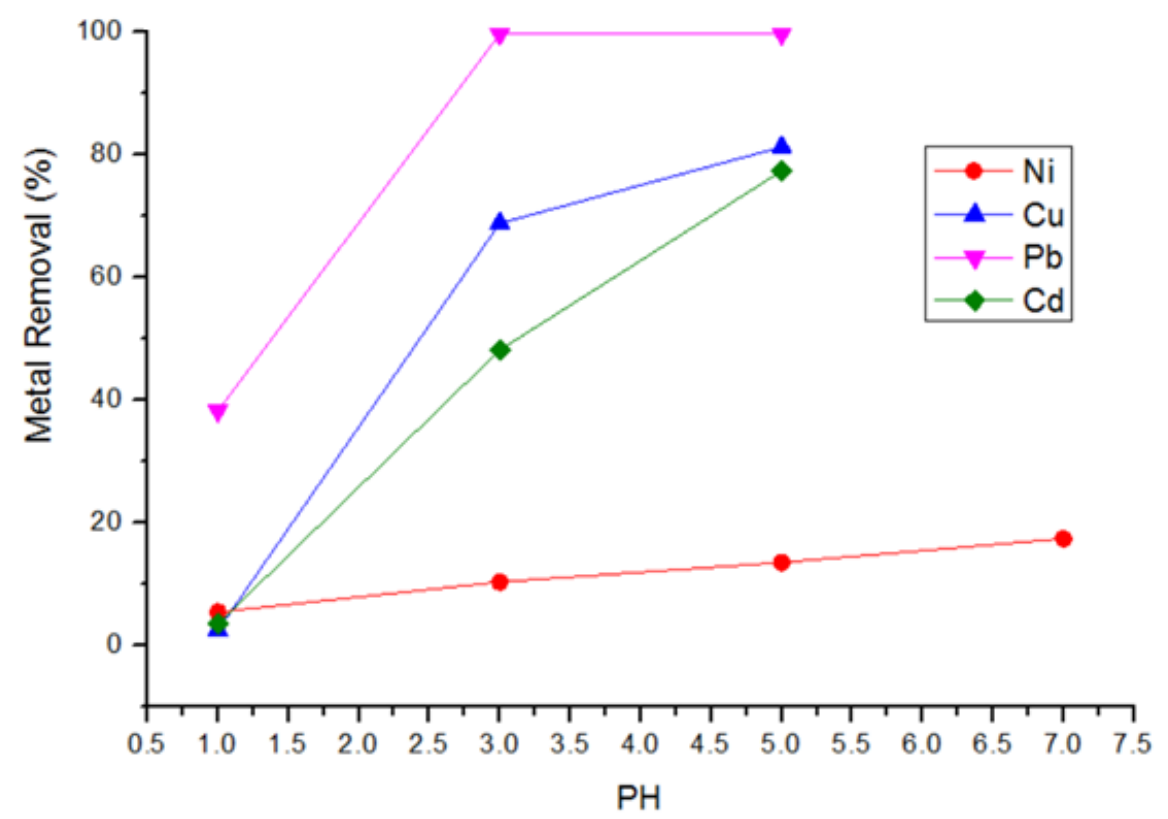

Fig. 6. Effect of pH on removal percentage of heavy metal ions by adsorbent $\mathrm{Fe}_{3} \mathrm{O}_{4}$ nanoparticles (initial metal concentration $=100 \mathrm{mg} \mathrm{L}^{-1}$, adsorbent dosage $0.1 \mathrm{~g}$ under ambient room temperature).

\section{Effect of adsorbent dosage on removal percentage of the studied pollutants}

The influence of nano-magnetite particle dosages is seen in Figure 7 which implies that generally increasing the quantity of nano- $\mathrm{Fe}_{3} \mathrm{O}_{4}$ sorbent ( $\mathrm{g}$ ) in the suspension, caused the percent of metals retention (q) or removal to increase. The highest removal of pollutants was observed at $0.25 \mathrm{~g}$ of nano- $\mathrm{Fe}_{3} \mathrm{O}_{4}$ (Fig.7). At this amount of sorbent nano-particles, about $99.86 \%$ of $\mathrm{Pb}^{2+}, 99.86$ of $\mathrm{Ni}^{2+}, 99.54 \%$ of $\mathrm{Cu}^{2+}$, and $96.42 \%$ of $\mathrm{Cd}^{2+}$ were removed. Thus, it was considered that $0.25 \mathrm{~g}$ is the optimum dosage.

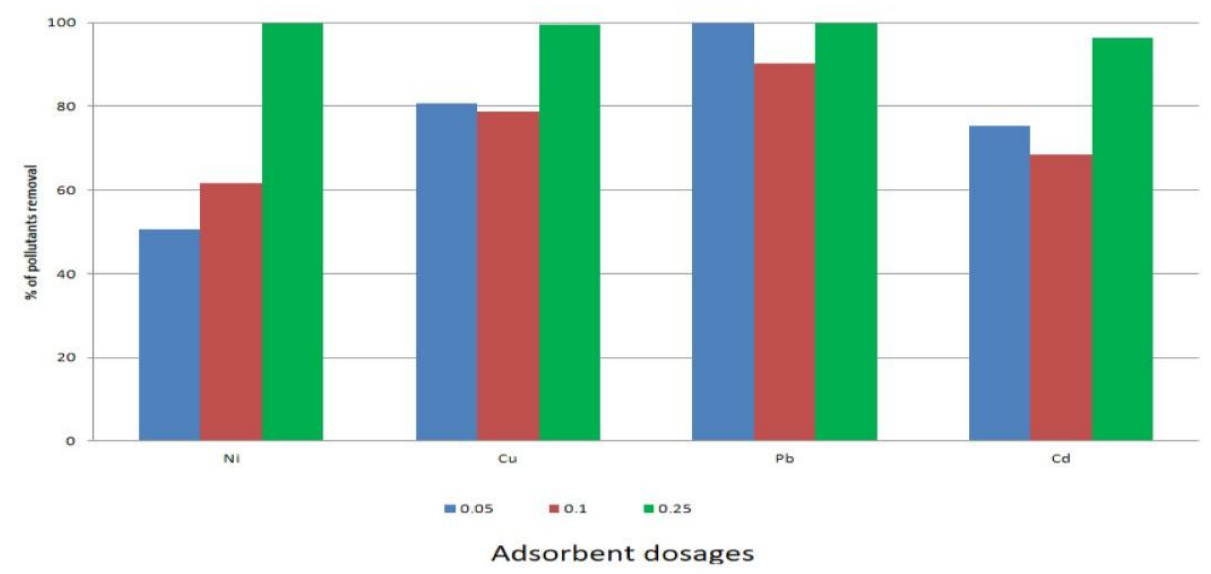

Fig. 7. Effect of adsorbent dose (g) on removal percentage of heavy metals by $\mathrm{Fe}_{3} \mathrm{O}_{4}$ adsorbent (initial metal concentration $=100 \mathrm{mg} \mathrm{L}^{-1}$, adsorbent weight, $0.05,0.1$ or $0.25 \mathrm{~g}$ and $\mathrm{pH}=5$ under ambient room temperature for 2 hours).

This behaviour of sorbent was expected due to increasing number of binding sites with the increased amount of absorbent (Lazaridis and Charalambous 2005; Chen and Yang, 2006). In other expression, the high sorption capacity exhibited by $\mathrm{Fe}_{3} \mathrm{O}_{4}$ 
Citation: Sherine Shehata Marid et al., Future Challenges for the Re-use of local waste water in agricultural applications: Utilization of iron oxide (magnetite) nanoparticles to remove the heavy metals. Australian Journal of Basic and Applied Sciences, 13(6): 39-50. DOI: 10.22587/ajbas.2019.13.6.5

could be ascribed by its nano-scale particle size giving access to larger surface area. These results fit well with the results documented by Meitei et al., (2013).

\section{Effect of suspension temperature on heavy metals sorption by nano- $\mathrm{Fe}_{3} \mathrm{O}_{4}$ Particles}

Figures 8 shows the sorption of the tested pollutants at different temperature regimes. Results clarify that the removal efficiency of the studied heavy metals is weakly influenced by temperature. In other words, numerically increasing of temperature regime of the system from $25{ }^{\circ} \mathrm{C}$ to $50{ }^{\circ} \mathrm{C}$, resulted in increases in the pollutants sorption by about $10,7,6$ and $5 \%$ for $\mathrm{Pb}, \mathrm{Cu}, \mathrm{Cd}$ and $\mathrm{Ni}$, respectively. Nevertheless, increasing the temperature from $40^{\circ} \mathrm{C}$ to $50{ }^{\circ} \mathrm{C}$ did not affect the pollutants sorption. This result reflects the low cost and much easier applicability of nano-magnetite technology in pollutant removal from contaminated water and also no needs to change the temperature of the system to increase these removals. Vilar et al., (2005) mentioned that the adsorption capacity gets its higher increase at the lowest temperature regime. Working above range of temperature $\left(>50^{\circ} \mathrm{C}\right)$ is avoided as at high temperatures, the structure of the magnetite would be changed and the active sites could be destroyed.

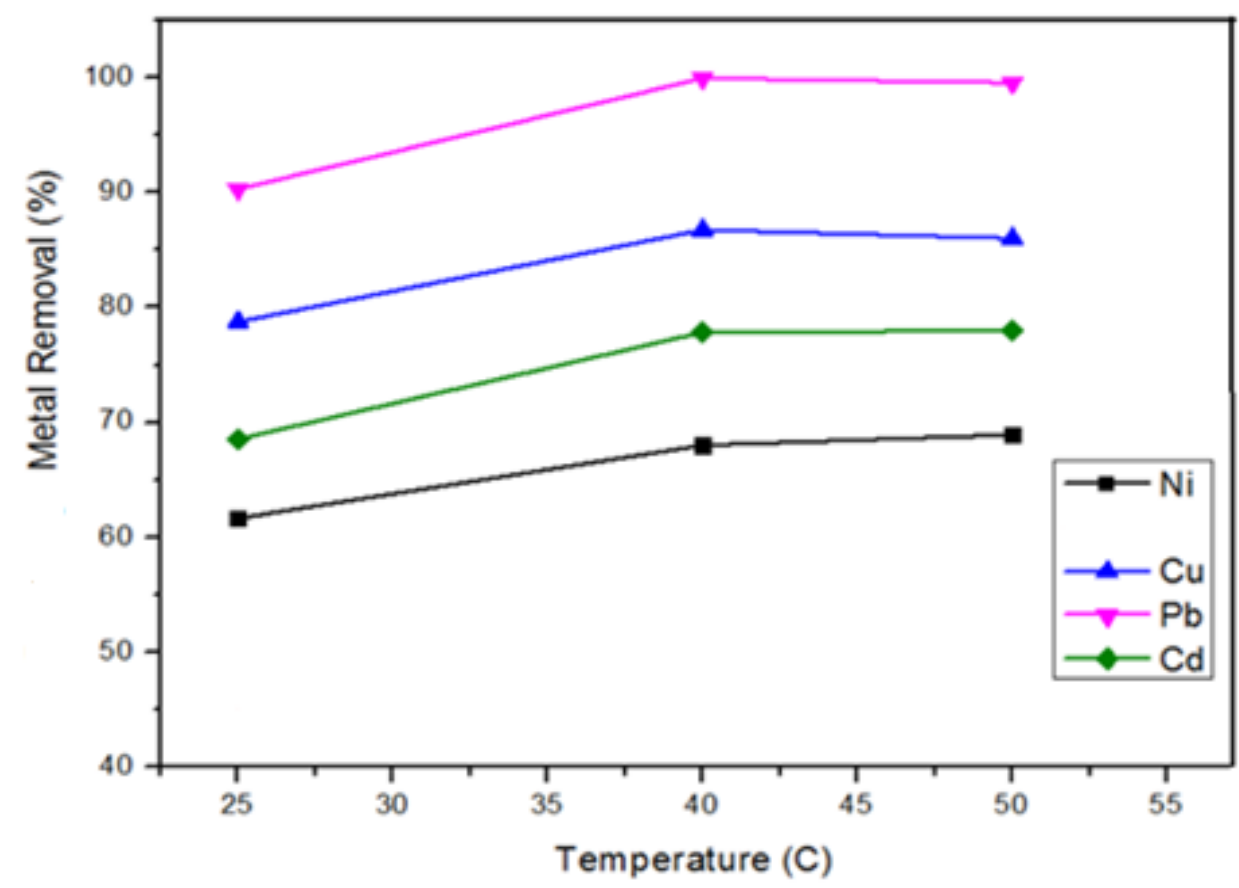

Fig. 8. Effect of temperature regime on heavy metals sorption on nano- $\mathrm{Fe}_{3} \mathrm{O}_{4}$ particles (initial metal concentration $=100$ $\mathrm{mg} \mathrm{L}^{-1}$, adsorbent weight, $0.1 \mathrm{~g}$, and $\mathrm{pH}=5$ for 2 hours).

Effect of pollutant concentrations in the contaminated water on the activity of sorbent material applied:

The initial metal concentration in polluted water is an important factor controlling the overcome all mass transfer resistances of metal ions at the solid-aqueous interface of our system, hence, increasing of metal concentration will increase the sorption process (Aksu, 2001). This factor is studied under the conditions of temperature, $25^{\circ} \mathrm{C}$; contact time, 2 hours and $\mathrm{pH}, 7$ for $\mathrm{Ni}^{2+}, 5$ for $\mathrm{Pb}^{2+}, \mathrm{Cu}^{2+}$ and $\mathrm{Cd}^{2+}$ of aqueous solutions prepared. The results in Figure (9) show that the capacity of metals removal by nano-material increased with increasing the initial $\mathrm{Pb}^{2+}, \mathrm{Ni}^{2+}, \mathrm{Cd}^{2+}$, and $\mathrm{Cu}^{2+}$ concentrations. The removal percentages increased from 86 to 99 and 87 to $95 \%$ by increasing the initial metal concentration from 1 to $50 \mathrm{mg} \mathrm{L}^{-1}$ for $\mathrm{Ni}^{2+}$ and $\mathrm{Cd}^{2+}$, respectively. The respective removal values were 97 increased to $99 \%$ for $\mathrm{Pb}^{2+}$. Increasing the initial concentration of metal ions from 1 to $100 \mathrm{mg} \mathrm{L}^{-1}, \mathrm{Fe}_{3} \mathrm{O}_{4}$ nanoparticles were found to be very efficient for adsorption of $\mathrm{Ni}$ (II), $\mathrm{Cd}$ (II) and $\mathrm{Pb}$ (II) compared to its bulk counterpart. Results of $\mathrm{Cu}^{2+}$ ions indicate that the sorption of metal ion rapidly increased till reached a maximum value 98 $\%$ at $5 \mathrm{mg} \mathrm{L}^{-1}$ concentration and slightly decreased to $95 \%$ when the ion concentration increased to $10 \mathrm{mg} \mathrm{L}^{-1}$. The hydrated ionic radii size may affect the interactions with the negative charged adsorption site. When the hydrated ionic radius increased, the distance to the adsorbing surface would increase and the adsorption would be weaker. Despite that $\mathrm{Pb}$ (II) had the least hydrated ionic radius and the maximum capability to compete with proton, it was reasonable that it had the highest adsorption capacity (Giraldo, et al., 2013). 
Citation: Sherine Shehata Marid et al., Future Challenges for the Re-use of local waste water in agricultural applications: Utilization of iron oxide (magnetite) nanoparticles to remove the heavy metals. Australian Journal of Basic and Applied Sciences, 13(6): 39-50. DOI: 10.22587/ajbas.2019.13.6.5

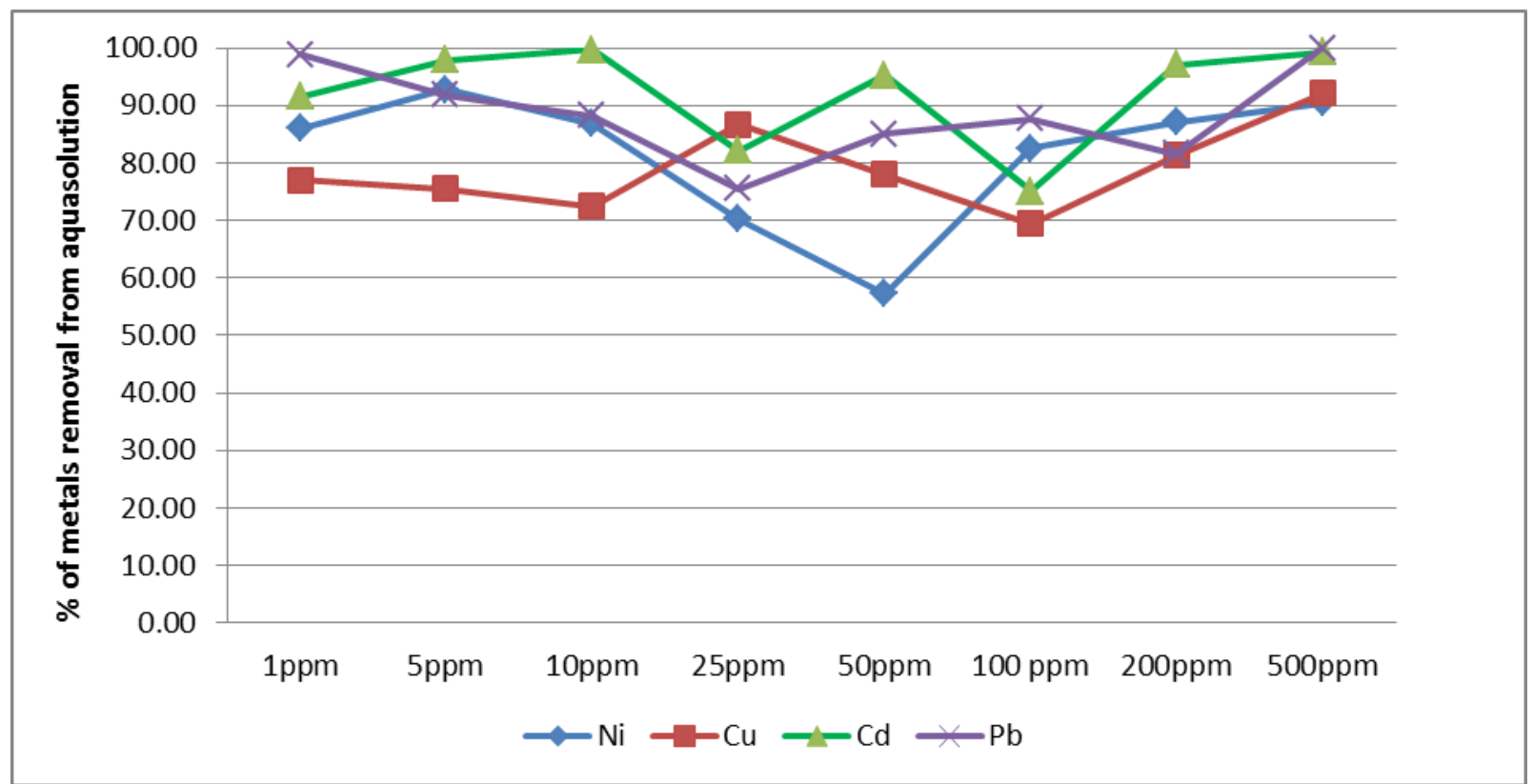

Fig. 9. Effect of different concentrations of heavy metals on the percentage of removal of $\mathrm{Ni}^{2+}, \mathrm{Pb}^{2+}, \mathrm{Cd}^{2+}$ and $\mathrm{Cu}^{2+} \mathrm{by}^{2}$ sorbent $\mathrm{Fe}_{3} \mathrm{O}_{4}$ material (sorbent weight, $0.1 \mathrm{~g}$, and $\mathrm{pH}=5$ under ambient room temperature for 2 hours).

Fitting of Equilibrium models in describing the adsorption isotherm of studied pollutants on the used nano-material:

In summary, Langmuir model represents one of the first theoretical approaches of non-linear sorption and implies that sorption takes places on a homogeneous surface by monolayer sorption without the interaction between adsorbed molecules. The Langmuir isotherm assumes that adsorbate in the solution occupies adsorption sites on the adsorbent surfaces. Langmiur isotherm model was applied to define the results of heavy metals sorption on nano-materials used in this work. The linear form of Langmiur isotherm equation is outlined by the equation:

Where:

$$
\begin{aligned}
& \mathrm{C}_{\mathrm{e}} / \mathrm{q}_{\mathrm{e}}=1 /\left(\mathrm{Q}_{\mathrm{e}} \mathrm{K}_{\mathrm{L}}\right)+\left(1 / \mathrm{Q}_{\mathrm{e}}\right) \mathrm{C}_{\mathrm{e}} \\
& \text { Or } \\
& \mathrm{C}_{\mathrm{e}} / \mathrm{q}_{\mathrm{e}}=1 /\left(\mathrm{q}_{\max } \times \mathrm{b}\right)+\left(1 / \mathrm{q}_{\max }\right) \times \mathrm{C}_{\mathrm{e}}
\end{aligned}
$$

$\left(\mathrm{C}_{\mathrm{e}}\right)$ is the metal concentration in aqueous solution at equilibrium $(\mathrm{mg} / \mathrm{L})$,

$\left(\mathrm{q}_{\mathrm{e}}\right)$ is the experimental amount of adsorbed metal at equilibrium $(\mathrm{mg} / \mathrm{g})$.

$\left(\mathrm{Q}_{0}\right)$ is the calculated amount of adsorbed metal at equilibrium $(\mathrm{mg} / \mathrm{g})$.

By plotting $\left(\mathrm{C}_{\mathrm{e}} / \mathrm{q}_{\mathrm{e}}\right)$ versus $(\mathrm{Ce})$, we can figure out the slope and intercept of the obtained straight line, respectively. As presented in Table (2), data imply that Langmuir's model well characterize the adsorption isotherm by having high coefficient of determination $\mathrm{R}^{2}$ ranged between $0.98^{* *}-0.99^{* *}$ and low standard error SE ranged between 0.01 - 0.02 for all pollutant's adsorption. Freundlich isotherm defines the adsorption equation for non-ideal adsorption that includes heterogeneous adsorption. This empirical isotherm is stated by the following equation:

$$
\mathbf{q}_{\mathrm{e}}=\mathbf{K}_{\mathrm{F}} \mathbf{C}_{\mathrm{e}}{ }^{\mathbf{1} \mathbf{n}}
$$

The equation is conveniently used in the linear form by taking the logarithm of both sides as:

Where:

$$
\log q_{e}=\log K F+(1 / n) \log C_{e}
$$

$\left(\mathrm{K}_{\mathrm{F}}\right)$ is the Freundlich constant indicating adsorption capacity;

(n) is the Freundlich constant indicating adsorption intensity.

By plotting $\left(\log \mathrm{q}_{\mathrm{e}}\right)$ versus $\left(\log \mathrm{C}_{\mathrm{e}}\right)$, $(\mathrm{n})$ and $\left(\mathrm{K}_{\mathrm{F}}\right)$ can be figured out from the slope and intercept of the obtained straight line, respectively (Antunes et al., 2003 and Cruz et al., 2004). The linearized Langmuir and Freundlich adsorption isotherms corresponded to $\mathrm{Ni}^{2+}, \mathrm{Cu}^{2+}, \mathrm{Pb}^{2+}$ and $\mathrm{Cd}^{2+}$ removing by the investigated nano magnetite $\left(\mathrm{Fe}_{3} \mathrm{O}_{4}\right)$ are represented in Figures $(10$ and 11). 
Citation: Sherine Shehata Marid et al., Future Challenges for the Re-use of local waste water in agricultural applications: Utilization of iron oxide (magnetite) nanoparticles to remove the heavy metals. Australian Journal of Basic and Applied Sciences, 13(6): 39-50. DOI: 10.22587/ajbas.2019.13.6.5

Effect of pollutants type on the constants of used models describing heavy metals sorption on the used nano-material

The Langmuir isotherm assumes that the adsorbate in the solution occupies adsorption sites on the adsorbent surfaces. The Langmuir constant (b), therefore, represents the adsorbate's degree of adsorption affinity. Usually expressed in (mg/g), the highest adsorption capacity $(\mathrm{Q})$ correlated with complete monolayer cover. The High value of $b$ suggests that metal ion adsorption has a much greater affinity. Increasing $\mathrm{Pb}$ value as shown in Table 2 implies that the highest affinity was detected between the used material and $\mathrm{Pb}$ followed by $\mathrm{Cu}, \mathrm{Cd}$ and finally $\mathrm{Ni}$ which showed the lowest affinity with Nono material. . Data presented in the same table showed that the calculated $\left(1 / \mathrm{Q}_{\mathrm{e}}\right)$ values which define the maximum capacities of the nano- $\mathrm{Fe}_{2} \mathrm{O}_{3}$ particles were arranged as $\mathrm{Pb}>\mathrm{Cd}>\mathrm{Ni}>\mathrm{Cu}$ in removing contaminants by the used material.

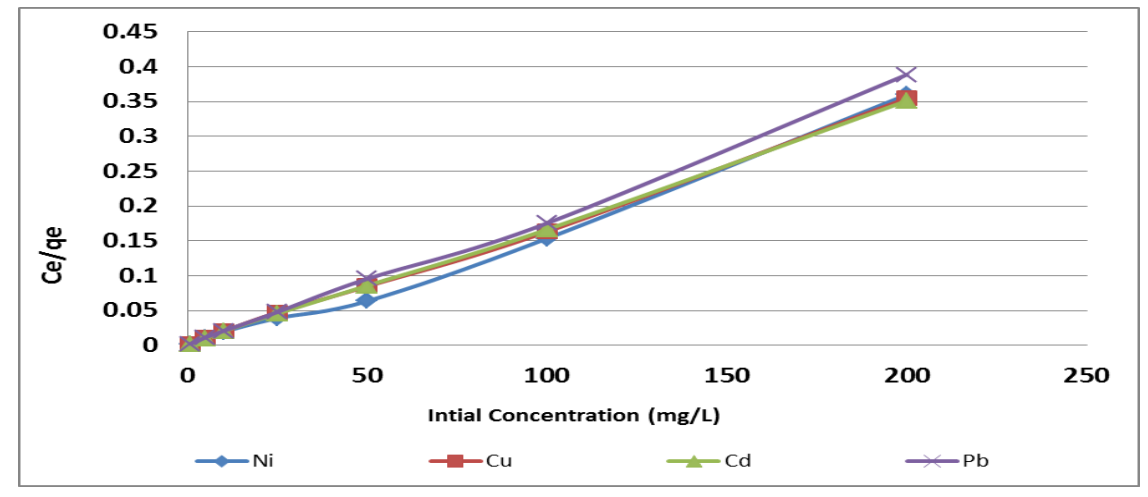

Fig.10. Linear form of langmiur isotherm for heavy metals adsorption onto nano $\mathrm{Fe}_{3} \mathrm{O}_{4}$ powder at temperature $\left(25^{\circ} \mathrm{C}\right)$.

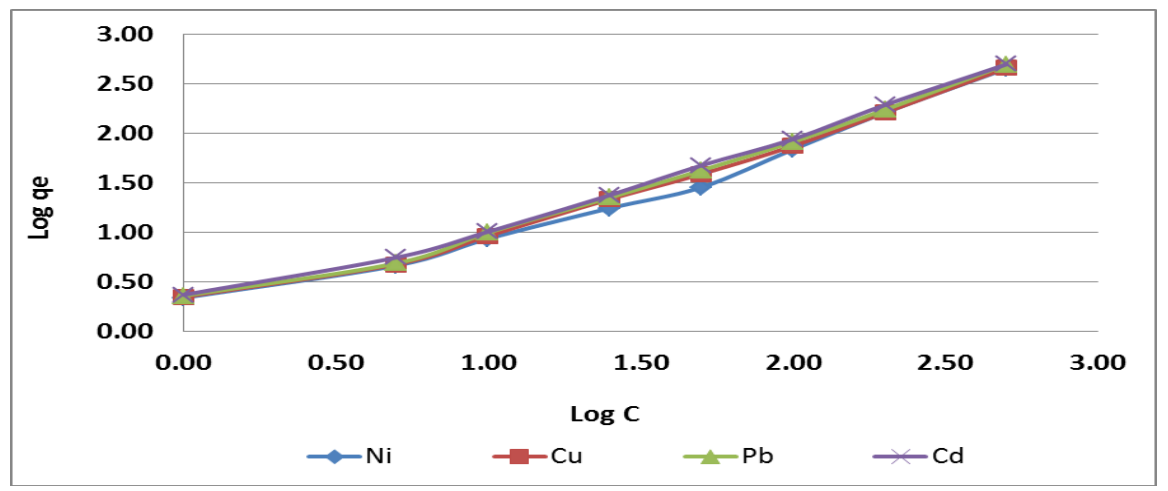

Fig.11. Linear form of Freundlich isotherm for heavy metals adsorption onto nano $\mathrm{Fe}_{3} \mathrm{O}_{4}$ powder at temperature $\left(25^{\circ} \mathrm{C}\right)$.

Freundlich isotherm is frequently used to define the heterogeneous surface adsorption characteristics. It reflects an original surface adsorption followed by a condensation impact arising from strong interaction between adsorbent and adsorbate. Freundlich isotherm curves are in the reverse direction of Langmuir isotherm and is exponential in shape. In many cases, the heat of adsorption reduces in magnitude with rising extent of adsorption. Accordingly, results showed that the highest value was observed for $\mathrm{Pb}$ followed by $\mathrm{Cd}, \mathrm{Cu}$ and the least value was tabulated in $\mathrm{Ni}$.

Table (2) Constants of Langmuir and Freundlich for heavy metals sorption by investigated nano-magnetite.

\begin{tabular}{|c|c|c|c|c|c|c|c|c|}
\hline \multirow[b]{2}{*}{ Metal } & \multicolumn{4}{|c|}{ Freundlich parameters } & \multicolumn{4}{|c|}{ Langmuir parameters } \\
\hline & $\mathbf{K}_{\mathbf{F}}$ & $\mathbf{n}$ & $\mathbf{R}^{2}$ & SE & $\begin{array}{c}1 / q \mathrm{qe} \\
* 10^{\wedge} 4\end{array}$ & $\begin{array}{c}1 /\left(q_{\max } \times b\right) \\
* 10^{\wedge} 4\end{array}$ & $\mathbf{R}^{2}$ & $\mathbf{S E}$ \\
\hline $\mathbf{N i}$ & 0.86 & 0.17 & $0.98 * *$ & 0.17 & 19.26 & -74.14 & $0.99 * *$ & 0.013 \\
\hline $\mathrm{Cu}$ & 0.89 & 0.12 & $0.98 * *$ & 0.15 & 49.74 & -64.96 & $0.99 * *$ & 0.030 \\
\hline $\mathbf{P b}$ & 0.98 & -0.04 & $0.99 * *$ & 0.13 & 16.53 & 3.94 & $0.99 * *$ & 0.005 \\
\hline Cd & 0.90 & 0.16 & $0.99 * *$ & 0.11 & 19.01 & -45.16 & $0.99 * *$ & 0.018 \\
\hline
\end{tabular}


Citation: Sherine Shehata Marid et al., Future Challenges for the Re-use of local waste water in agricultural applications: Utilization of iron oxide (magnetite) nanoparticles to remove the heavy metals. Australian Journal of Basic and Applied Sciences, 13(6): 39-50. DOI: 10.22587/ajbas.2019.13.6.5

\section{Conclusion}

Crystalline- $\mathrm{Fe}_{3} \mathrm{O}_{4}$ nanoparticles could act as alternatives to the conventional adsorbents for removing metal ions from polluted water with high removal efficiency within a very short time period. This work examined the $\mathrm{Ni}^{2+}, \mathrm{Cd}^{2+}, \mathrm{Pb}^{2+}$ and $\mathrm{Cu}^{2+}$ retention using nano- $\mathrm{Fe}_{3} \mathrm{O}_{4}$ particles as a new sorbent. Pollutant removal was greatly dependent on the $\mathrm{pH}$ of the contaminated water. The maximum removal efficiency was obtained at $\mathrm{pH} 7$ for $\mathrm{Ni}^{2+}$ and $\mathrm{pH} 5$ for the other pollutants at room temperature. Also, the Langmuir and Freundlich equilibrium models well interpreted the sorption data of the studied metals. According to the constants of the used models, the sorption mechanism between metal ions and iron oxide nanoparticles appears to be mainly chemisorption followed by precipitation and also could be affected by the hydrated ionic radius of the metal cations studied. It could be deduced that $\mathrm{Fe}_{3} \mathrm{O}_{4}$ nanoparticles can be recommended as a fast, effective, and inexpensive nano-sorbents for rapid removal of pollutants ions contaminating waters.

\section{AUTHOR CONTRIBUTION}

Conceived \& designed the experiments: Sherine S. Marid, Sahar M. Ismail and Nehal A. Ali, Performed the experiments: Sherine S. Marid, Sahar M. Ismail and Nehal A. Ali, Prepared the tables and figures and analyzed the data: Sherine S. Marid and Nehal A. Ali, Wrote the paper: Nehal A. Ali and Sahar M. Ismail.

\section{Acknowledgement}

The authors would gratefully acknowledge the staff members in the Soil physics and chemistry Department, Desert Research Center, Cairo, Egypt and Center of Imaging and Microscopy, Zewail City of Science and Technology, Cairo, Egypt for providing the laboratories and for technical support in the implementation of this study.

\section{Conflict of Interest}

This research did not receive any specific grant from any funding agency. The authors declare that there are no conflicts of interest.

\section{REFERENCES}

Akinci, G.; D. E. Guven, and Ugurlu, S. K. 2013. "Assessing pollution in Izmir Bay from rivers in western Turkey: heavy metals" Environmental Science, vol. 15, no. 12, pp. 2252-2262.

Aksu, Z. 2001. "Equilibrium and kinetic modeling of cadmium (II) bio-sorption by C. vulgaris in a batch system: effect of temperature". Sep. Purif. Technol., 21, 285-294.

Al-Musharsfi, S. K.; I. Y. Mahmoud, and S. N. Al-Bahry. 2013. "Heavy metal pollution from treated sewage effluent" APCBEE Procedia, vol. 5, pp. 344-348.

Antunes, W. M.; A. S Luna, C. A. Henriques, and A. C. A. da Costa. 2003.” Optimized conditions”. Elec. J. Biotechnol. 6 (3), 174-184.

Araneda, C.; C. Fonseca, J. Sapag, C.; Basualto, M. Yazdani-Pedram, K. Kondo, E. Kamio, and F. Valenzuela, 2008. "Removal of metal ions from aqueous solutions by sorption onto microcapsules prepared by copolymerization of ethylene glycol dimethacrylate with styrene". Sep. Purif. Technol. 6, 517-523.

Banfield, J.F. and Zhang, H. 2001. "Nanoparticles in the environment". In: Ribbe, P.H., Rossi, J.J. (eds.) Nanoparticles and the environment. The Mineralogical Society of America, Washington, DC.

Bloomfield, L. A. (Last Updated on 2009, February 19). 2011. "Water Purification”. Retrieved September 15, from How Every Things Works http://www.howeverythingworks.org/supplements/water_purification.pdf

Büchner, W., R. Schliébs, G. Winter, and K. H. Bucjel. 1989. "Primary inorganic materials”. In D. H. Dyllick-Brenzinger., pp 812 in "Industrial inorganic chemistry". New York: Verlagsgesellschaft.

Chen, J.P, L .Yang 2006. "Study of a previous term heavy metal next term biosorption onto raw and chemically modified Sargassum sp. via spectroscopic and modeling analysis". Langmuir 22:8906-8914.

Cruz, C. C. V., da Costa, C. A. Henriques, and Luna, A. S. 2004. "Kinetic modeling and equilibrium studies during cadmium biosorption by dead Sargassum sp. biomass". Biores. Technol., 91, 249-257.

Farea, A.M.M., Kumar, S.; Batoo, K.M. and Yousef, A. 1999. Alimuddin, Physics B 403: (2008) 684-701.

Feng, Z., S. Zhu, De Godoi, D. R. M., Samia, A. C. S and Scherson. D. 2012. "Adsorption of Cd ${ }^{2+}$ on carboxyl-terminated super paramagnetic iron oxide nanoparticles," Analytical Chemistry, vol.84: no.8, pp.3764-3770.

Fujita, M., lde, Y. and Sato. D. 2014. "Heavy metal contamination of coastal lagoon sediments: Fongafale islet, Funafuti atoll, tuvalu" Chemosphere, vol. 95: pp. 628-634.

Giraldo, L., Erto, A. and Moreno-Piraján, J.C. 2013. "Magnetite nanoparticles for removal of heavy metals from aqueous solutions: Synthesis and characterization". Adsorption, 19: 465-474.

Gonza'lez, F., F.A. Bonilla, G.; Zambrano, M.E. Go'mez, and J.A. Lopez. 2010. "Synthesis and characterization of Fe ${ }_{3} \mathrm{O}_{4}$ magnetic nano fluid". RLMM. 30: 60-66.

Gul, I. H., A.Z. Abbasi, F. Amin, M. Anis-ur-Rehman, and A. Maqsood, 2007. Journal of Magnetism and Magnetic Materials 311: 494-499. 
Citation: Sherine Shehata Marid et al., Future Challenges for the Re-use of local waste water in agricultural applications: Utilization of iron oxide (magnetite) nanoparticles to remove the heavy metals. Australian Journal of Basic and Applied Sciences, 13(6): 39-50. DOI: 10.22587/ajbas.2019.13.6.5

Gupta, V.K., S. Agarwal, and T.A. Saleh 2011. "Synthesis and characterization of alumina-coated carbon nanotubes and their application for lead removal". J. Hazard Mater 185: 17-23.

Gupta, V. K, A.Nayak, 2012. "Cadmium removal and recovery from aqueous solutions by novel adsorbents prepared from orange peel and $\mathrm{Fe}_{2} \mathrm{O}_{3}$ nanoparticles". Chem. Eng. J. 180: 81-90.

Hu, J., G. Chen, I. M. Lo, and M. Asce. 2006. "Selective Removal of Heavy Metals from Industrial Wastewater Using Maghemite Nanoparticle: Performance and Mechanisms," Journal of Environmental Engineering, 132: pp.709-715.

Hua, M., S. Zhang, B. Pan, W. Zhang, L. Lv, and Q. Zhang. 2012. "Heavy metal removal from water/wastewater by nanosized metaloxides: a review," Journal of Hazardous Materials, vol.211-212: pp.317-331.

Johnson, S. B., G. V. Franks, S P. J. cales, D. V. Boger, and T. W. Healy. 2000 "Surface chemistry-rheology relationships in concentrated mineral suspensions," International Journal of Mineral Processing, vol. 58, no. 1-4, pp. $267-304$.

Karatapanis, E., D. E. Petrakis, and C. D. Stalikas. 2012. "A layered magnetic iron/iron oxide nanoscavenger for the analytical enrichment of ng-L-1 concentration levels of heavy metals from water," Analytica Chimica Acta, vol. 726:22-27.

Kharisov, B. I. , H. V. R. Dias, O. V. Kharissova, V. M. Jim ' enezP'erez, B. O. P' erez, and B. M. Flores. 2012. 'Iron-containing nanomaterial: synthesis, properties, and environmental applications,"RSC Advances, vol.2: no.25, pp.9325-9358.

Koop, T., A. Kapilashrami, L. T. Molina and M. J. Molina. 2000." Phase transitions of sea-salt/water mixtures at low temperatures: Implications for ozone chemistry in the polar marine boundary layer, J. Geophys. Res., $105: 26393-26$ 402.

Laurent, S., D. Forge, M. Port et al., 2008. "Magnetic iron oxide nanoparticles: synthesis, stabilization, vectorization, physicochemical characterizations, and biological applications." Chemical Reviews, vol.108: no.6, pp.2064-2110.

Lazaridis, N.K., C. Charalambous. 2005. "Sorptive removal of trivalent and hexavalent chromium from binary aqueous solutions by composite alginate-goethite beads". Water Res 39: 4385-4396.

Lee, S. M, C. Laldawngliana, and D. Tiwari. 2010. "Iron oxide nano-particles- immobilized-sand material in the treatment of $\mathrm{Cu}$ (II), Cd (II) and Pb (II) contaminated wastewaters". Chem. Eng. J. 195-196: 103-111.

Lee, J., S. Mahendra, P.J.J. Alvarez. 2010. "Nanomaterials in the construction industry: A review of their applications and environmental health and safety considerations". ACS Nano 4: 3580-3590.

Liu, Z., H. Wang, and C. Liu. 2012. "Magnetic cellulose-chitosan hydrogels prepared from ionic liquids as reusable adsorbent for removal of heavy metal ions," Chemical Communications, vol. 48: no. 59, pp. 7350-7352.

Mahmoudi, M., S. Sant, B. Wang, S. Laurent, and T. Sen, 2011. "Super paramagnetic iron oxide nanoparticles (SPIONs): development, surface modification and applications in chemotherapy," Advanced Drug Delivery Reviews, vol. 63: no. 1-2, pp. $24-46$.

Mansour, M. S; M. E. Ossman, H. A. Farag. 2011. "Removal of Cd (II) ion from wastewater by adsorption onto polyaniline coated on sawdust". Desalination 272: 301-305.

Meitei, M. D, M. N. V. Prasad. 2013. "Lead (II) and cadmium (II) biosorption on Spirodelapolyrhiza (L.) Schleiden biomass”. J. Environ. Chem. Eng. 1: 200-207.

Naser, H. A. 2013. "Assessment and management of heavy metal pollution in the marine environment of the Arabian Gulf, a review" Marine Pollution Bulletin, vol. 72: no. 1, pp. 6-13.

Oh, J. K. and J. M. Park. 2011. "Iron oxide-based super paramagnetic polymeric nano-materials: design, preparation, and biomedical application,’Progress in Polymer Science, vol.36: no.1, pp.168-189.

Reddy, L. H., J. L. Arias, J. Nicolas, and P. Couvreur 2012. "Magnetic nanoparticles: design and characterization, toxicity and biocompatibility, pharmaceutical and biomedical applications," Chemical Reviews, vol.112, no.11, pp.5818-5878

Rickerby, D., M. Morrison. 2007. "Report from the Workshop on Nanotechnologies for Environmental Remediation". JRC Ispra. Available at www.nanowerk.com/nanotechnology/reports/reportpdf/report101.pdf.

Roonasi, P. and A. Holmgren, 2009."An ATR-FTIRstudy of sulphate sorption on magnetite; rate of adsorption, surface speciation, and effect of calcium ions.” Journal of Colloid and Interface Science, vol. 333: no. 1, pp. $27-32$.

Schwarzenbach, R. P., T. Egli, T. B. Hofstetter, U. Von Gunten, and B. Wehrli. 2010. "Global water pollution and human health" Annual Review of Environment and Resources, vol. 35: pp. 109- 136.

Shao-hua, J. U; L. U Shuai-dan, P. Jin-hui, Z. Li-bo, and C. Srinivasakannan. 2012. "Removal of cadmium from aqueous solutions using red mud granulated with cement". Transactions of Nonferrous Metals Society of China 22: 3140 - 3146.

Simamora, P., C.S. Saragih, D.P. Hasibuan, and Juniastel Rajagukguk 2018. "Synthesis of nanoparticles Fe3O4 /PEG/PPy-based on natural iron sand". Materials Today: Proceedings 5: 14970 - 14974.

Srivastava, N. K and C. B Majumder 2008. "Novel biofiltration methods for the treatment of heavy metals from industrial wastewater". J, Hazard Mater 151: 1-8.

Sunil J. and M.D. Wimalawansa, 2013. "Purification of Contaminated Water with Reverse Osmosis: Effect ive Solution of Providing Clean Water for Human Needs in Developing Countries". International Journal of Emerging Technology and Advanced Engineering, Volume: 3 Issue 12.

Shoeb A. M., K. Ansari, E. Ficiarà, F. A. Ruffinatti, I. Stura, M. Argenziano, O. Abollino, R. Cavalli, C. Guiot and F. D’Agata. 2019 "Magnetic Iron Oxide Nanoparticles: Synthesis, Characterization and Functionalization for Biomedical Applications in the Central Nervous System" Materials MDPI, 12: (3), 465; https://doi.org/10.3390/ma12030465

Zhang L., and Fang, M. 2010 "Nanomaterials in pollution trace detection and environmental improvement," Nano Today, vol. 5: no.2, pp.128-142. 